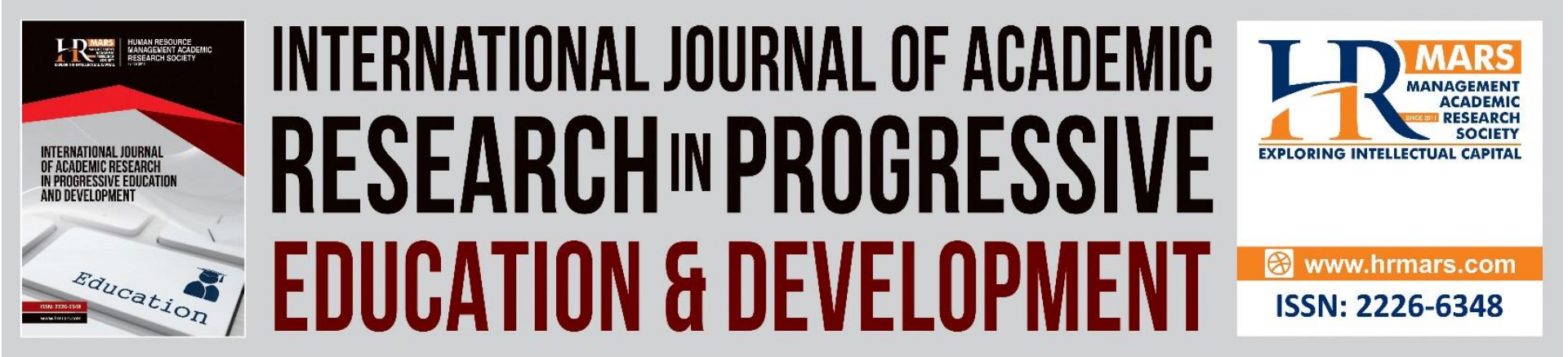

\title{
Econometric Analysis of FDI in the Mining Sector to Tanzania's Export Capacity
}

Johansein Rutaihwa, Aneth Simwela

To Link this Article: http://dx.doi.org/10.6007/IJARPED/v1-i4/12008

DOI: $10.6007 /$ IJARPED/v1-i4/12008

Received: 18 September 2012, Revised: 21 October 2012, Accepted: 03 November 2012

Published Online: 28 November 2012

In-Text Citation: (Rutaihwa \& Simwela, 2012)

To Cite this Article: Rutaihwa, J., \& Simwela, A. (2012). Econometric Analysis of FDI in the Mining Sector to Tanzania's Export Capacity. International Journal of Academic Research in Progressive Education and Development, 1(4), 132-148.

Copyright: @ 2012 The Author(s)

Published by Human Resource Management Academic Research Society (www.hrmars.com)

This article is published under the Creative Commons Attribution (CC BY 4.0) license. Anyone may reproduce, distribute, translate and create derivative works of this article (for both commercial and non-commercial purposes), subject to full attribution to the original publication and authors. The full terms of this license may be seen at: http://creativecommons.org/licences/by/4.0/legalcode

\section{Vol. 1(4) 2012, Pg. 132 - 148}

Full Terms \& Conditions of access and use can be found at http://hrmars.com/index.php/pages/detail/publication-ethics 


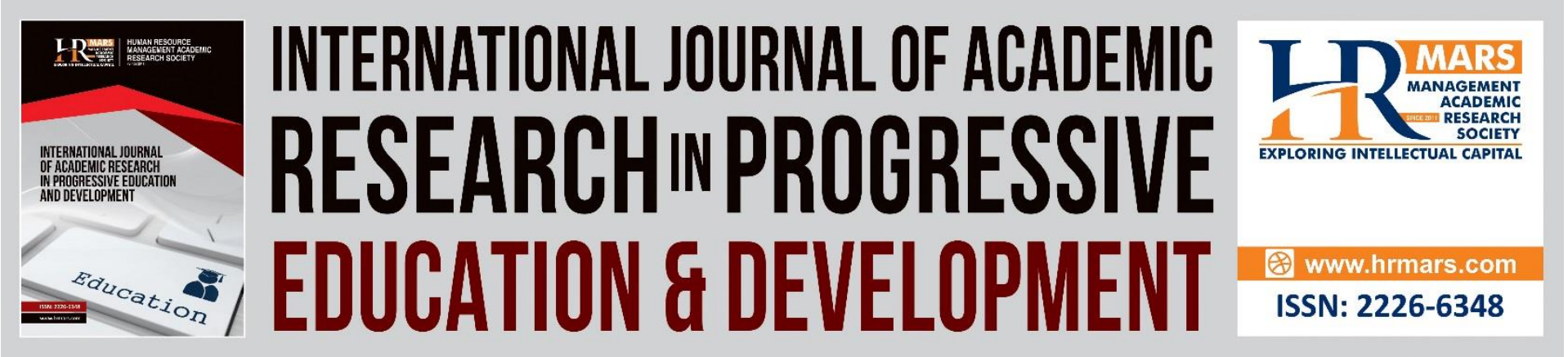

\title{
Econometric Analysis of FDI in the Mining Sector to Tanzania's Export Capacity
}

\author{
Johansein Rutaihwa \\ Policy Research for Development (REPOA), Tanzania \\ Aneth Simwela \\ Ministry of Industry and Trade (MIT), Tanzania
}

\begin{abstract}
This study concentrated in examining the role FDI in the Mining Sector to Tanzania's Export Capacity during 1989-2009. The study uses Ordinary Least Squares (OLS) as analytical techniques for this purpose. The results from OLS show that the total exports performance to the rest of the world is negative and insignificant, which implies that the contribution of FDI in mining have been weakly and exerting negative pressure on Tanzania's export performance over the period. The result on the relationship between Tanzania export performance and FDI in mining shows to be statically insignificant however it confirms the hypothesis of the positive relationship among the variables, this kind of results can justify that the benefits deriving from mining transformation do not turn up within the period when the investments are made, but possibly it takes some time for this to record. It is therefore, suggested that there is a need to sustain current inflows and attract new FDI, but can be adjusted by enhancing the domestic investments in mining sector; addressing the supply and demand side constrains; accelerating growth in the sector by the interventions in reviewing and implementation of Mining Policy by targeting at value addition and improve export performance; facilitate exports of final products made of minerals rather than focusing on exporting raw gold, Tanzanite, diamond and other minerals; improve physical infrastructure both transport and communication sectors; think in terms of quality, not quantity ,provide a link between small scale producers and large scale mining companies to ensure that both parties are benefiting from the sector; facilitate research and development in the mining sector; align mining policies and other local and environmental policies to ensure sustainable development in the sector; and Provide a transparent and appropriate incentive and regulatory framework.
\end{abstract}

Keywords: FDI, Export Capacity, Mining, Ordinary Least Squares

\section{Background to the Study}

As a result of globalization and liberalization, integration among countries has increased leading to increased capital flows (Asseri, 2009). Capital flow is grouped into two forms namely Foreign Direct Investment (FDI) and Portfolio Direct Investment (PDI). According to World Bank report (2007) trends have shown that FDI inflows have dominated over PDI in 
developing countries and that FDI net flow are less volatile in comparison to developed economies. Subsequently, foreign direct investment is more encouraged almost in all developing countries. According to Kumar and pardhan, 2001, FDI has emerged as the most important source of external resource flows to developing countries over the 1990s, thus it has been e very influential instrument in economic development for both developed and developing countries by enabling these countries to build up physical capital, create employment opportunities, develop productive capacity, exports and increased pace of transfer of and help integrate the domestic economy with the global economy.

Many studies on this areas postulate that FDIs can play a significant role in generating export supply to enable countries expand their international trade. It is often thought that foreign firms, particularly multi-national corporations usually have already established production, distribution and marketing networks and hence are more likely to engage in export oriented activities than local firms do. Hence it is mainly for these reasons that most countries today are seeking to attract foreign investment. In line with this thinking, these advantages could filter through to local firms, and thereby increase their capacity to export as well. This view appears to be widespread, as most countries have recognized the importance of FDI inflows for their economic growth, poverty alleviation and development in general. As a result, there have been increasing efforts made by many countries to attract new investments from abroad, evidenced by the establishment of investment promotion agencies in most countries.

Tanzania like other developing countries has opened up her economy and encourages foreign direct investment inflows. This can be traced back to the Structural Adjustment Programme spearheaded by the Bretton Woods institutions in the early 1980s. The macroeconomic policy changes that were made included the introduction of a floating exchange rate, liberalization of parastatals, tax and financial reforms, and trade and investment promotion (ESRF, 2002; Saruni, 2006). These changes were intended to allow more private investments to be sourced domestically and internationally. As a result of this, Tanzania is becoming a major FDI destination in Africa. The country is ranked among the top dozen FDI recipients in Africa excluding oil producing countries and South Africa. The below figure 1 shows from 1990 to 1995, FDI inflows totalled US\$ 232 million, compared to US\$ 1.3 billion from 1996 to 2000. Subsequently from 2000 onwards, FDI inflows accelerated, growing at an annual average of 28 percent from 2003 to 2008 but for 2009, FDI inflows declined as the results of financial crisis of 2008.

Figure 1: Annual Tanzania FDI inflows, 1990 - 2009 (in US\$ millions)

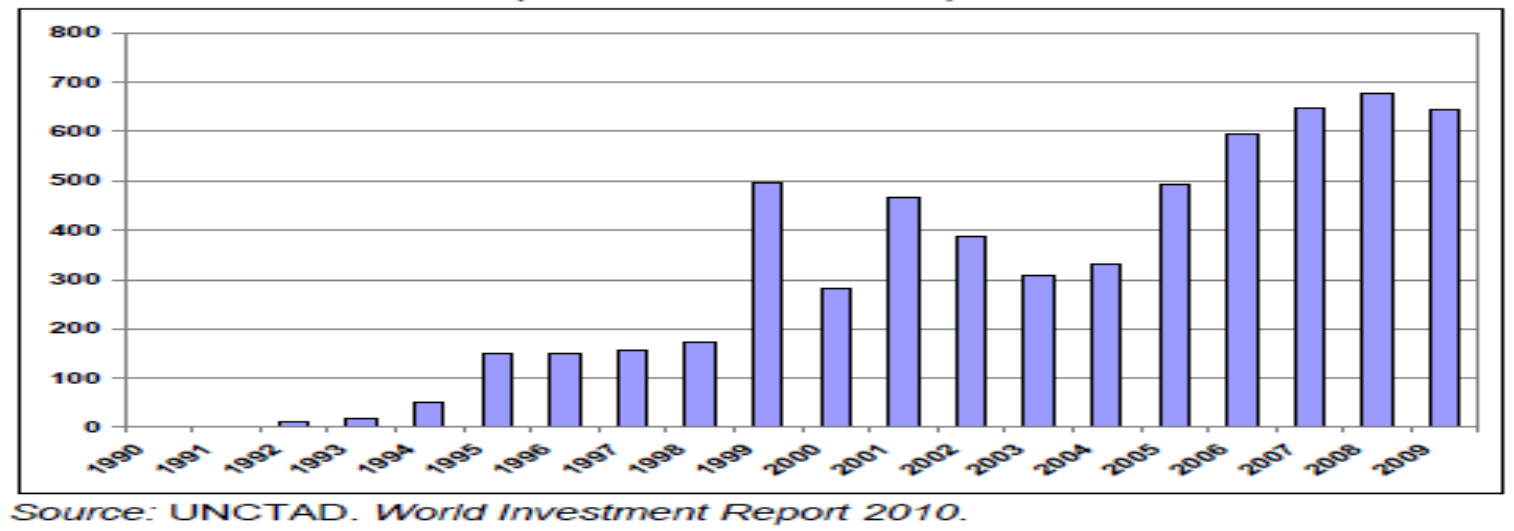


DEVELOPMENT

Vol. 1, No. 4, 2012, E-ISSN: $2226-6348$ @ 2012 HRMARS

By the end of 1990s, mining has been and continues to be one among the main source of FDI inflows. In 2000, AngloGold began operations in the United Republic of Tanzania, followed by Barrick Gold in 2001. From 2001 to 2009, Barrick Gold alone opened four mines. FDI stock surged from US\$2.78 billion in 2000 to US\$ 5.94 billion in 2007. During this period of growth, over US\$ 2 billion out of a total increase of US\$ 3 billion was due to mining. Other sources of FDI include smaller projects in manufacturing and tourism. (World Investment report 2010).

Comparing the flow of FDI in Tanzania and other developing countries, the studies shows that the amount of foreign direct investment increased significantly for developing economies during 1985 to 2000. Absolute levels of FDI to African countries have increased from an annual average of $\$ 1.9$ billion in 1983-87 to US\$ 3.1 billion in 1988-1992 and \$6 billion in 1993-1997 (UNCTAD, 1999). In 1990 sub-Saharan Africa received US\$ 923 million in FDI which rose to US\$ 7949 million in 1999 (World Development Indicators, 2001). According to Loots (1999) $15.3 \%$ of FDIs in Africa in 1997 was in the primary sector, of which $60 \%$ went to mining and natural resource extraction, including fossil fuels.

The share of developing countries in the world FDIs inflows and outflows has risen from $17.4 \%$ in $1985-90$ to $26.1 \%$ during $1995-2000$ (see figure 2). At the same time, evidence shows that the share of world trade accounted for by foreign firms have grown (UNCTAD, 2002). This has brought significant changes in both trade patterns and trade performance of many countries. This expansion of FDI has been contributed by the removal of barriers to the movements of capital and goods, as well as measures to enhance trade integration within the regional and global markets.

Figure 2: Share of Tanzania FDI Inflow into LDCs and Sub-Saharan Africa (\%)

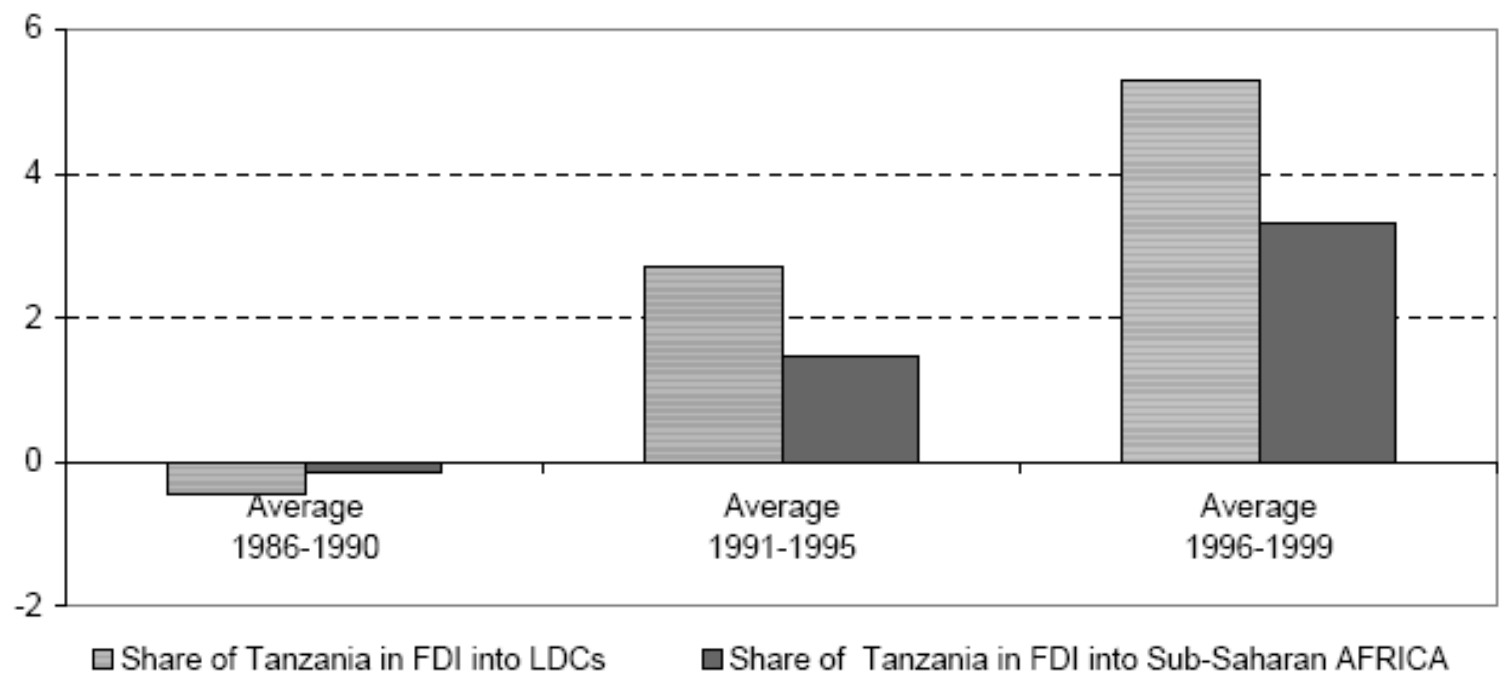

Source: UNCTAD, FDI/TNC database.

This is evidenced by the growing number of international investment and trade agreements. The number of preferential trade agreements with investment provisions has almost doubled in the past five years. Developing countries are becoming increasingly important participants in international investment rule-making, partly reflecting growing South to South Cooperation in trade and FDI (UNCTAD, 2006). 
DEVELOPMENT

Vol. 1 , No. 4, 2012, E-ISSN: $2226-6348$ @ 2012 HRMARS

Basing on the brief background given, there has been a considerable debate among Scholars and Policy makers on how FDI in mining (FDIM) affects the host country's economic performance in general. One of the critical issues debated has been whether FDIM is a stimulant of the host country's export performance, thus this study will seek to examine the share of total FDI going to the Mining Sector; examine the role of FDI in the Mining Sector to Tanzania's Export performance and to draw relevant policy recommendations.

\section{Overview of Tanzania's Export Sector}

In its efforts to increase export supply capacity, Tanzania adopted liberalization policies in the early 1990s which included a number of reforms help to reorienting country's economic policies towards an export-oriented growth strategy. These included establishments of the Export Processing Zones, usually referred to as multi-facility economic zones. The role of FDIs in promoting Tanzania's exports can be confirmed by the fact that total exports by foreign owned enterprises in Tanzania have been increasing.

Today, Tanzania exports performance has exhibited a dramatic change of exports pattern from agricultural traditional products to non-traditional products with the emergence of minerals specifically gold, gemstone and Tanzanite. Statistics show the value of traditional exports remained minimal compared to nontraditional exports, whereby the value of nontraditional exports was US\$2,270.6 million and US\$ 1,704.5 million in 2008 and 2007 respectively, representing to an increase of 28.8 percent (Economic Survey, 2008). However the value of traditional exports was USD 319.7 million and USD 418.4 million in 2008 and 2007 respectively (Economic Survey, 2008).

The mineral exports account for more than 40 percent of Tanzania total exports. It is the fastest growing sector. Mining sector accounted for 3.2 percent of GDP by 2005 (URT, 2005); Tanzania Development Vision 2025 projects the sector to contribute more than $10 \%$ of GDP by 2025 . However, the statistics show that although Tanzania economy has improved, over the years the country still remains poor.

Figure 3: FDI and Export performance in Tanzania (in US\$ million)

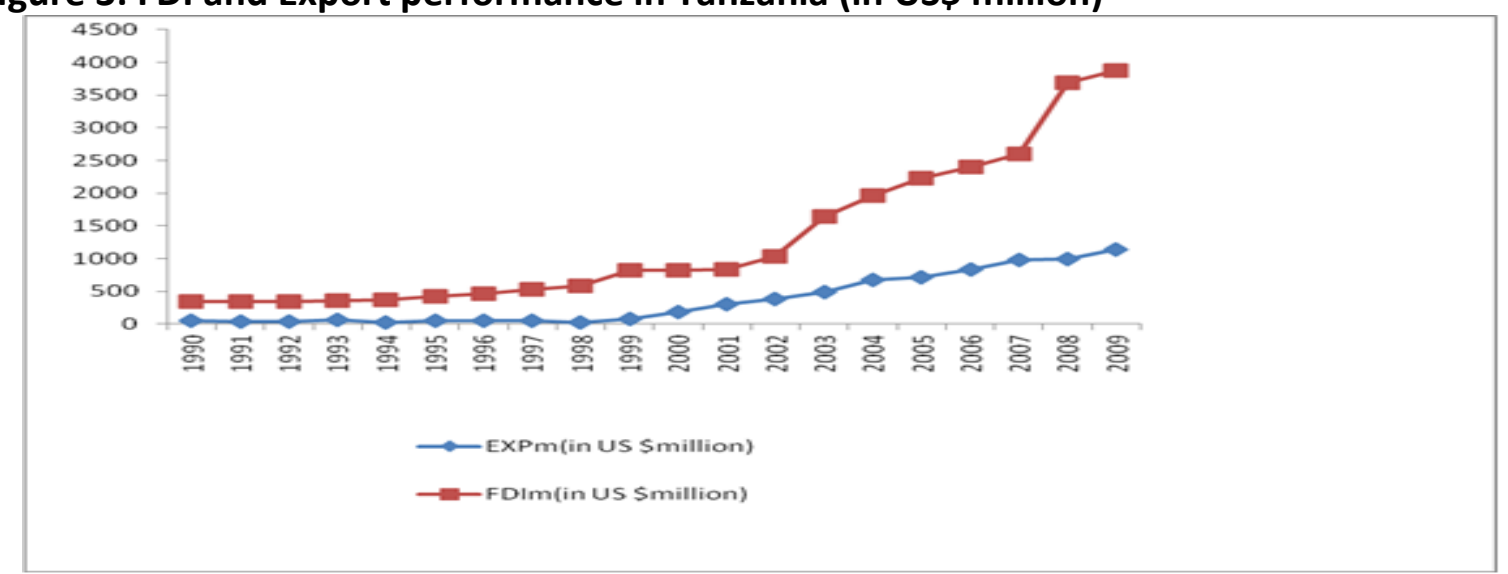

Source: Economic survey, 2009

\section{Tanzania's Export Markets}

Historically, the European Union (EU) has been Tanzania's most important trading partner, owing to the preferences the country has enjoyed. An analysis of COMTRADE data over the 
period 2001 to 2007 reveals that there has been a significant shift in Tanzania's export markets over the period. Nearly 40 per cent of Tanzania's exports go to China, India, Netherlands, Germany and United Arab Emirates. This can be explained by the goods being exported to other regions such as China, which have gained prominence over the years. The emergence of Asia as a trading partner for Tanzania's is a result of the increase in the demand for timber, cotton and met due the growing economies of China and India, which have increased exports of timber, meat and cotton to the region.

In the most recent years, there has been a shift in export markets to the Southern African Development Community (SADC) and the East African Community (EAC) regions, which have become Tanzania's major export destinations, followed by the EU and Asia. Within the SADC region, South Africa continues to stand out as Tanzania's most important trading partner. The shift to regional trade can be explained by the strong investment capacity of South Africa, which remains the most vibrant economy as well as the most important trading partner for most countries in the bloc.

\section{Tanzania's FDI in Mining Performance}

The country has witnessed FDI inflows upsurge in the mining sector with relatively low inflows in other key sectors of the economy, especially tourism and agriculture (Tanzania Investment Report, 2006).

Figure 1: Tanzania's FDI in Mining performance (in US\$ million)

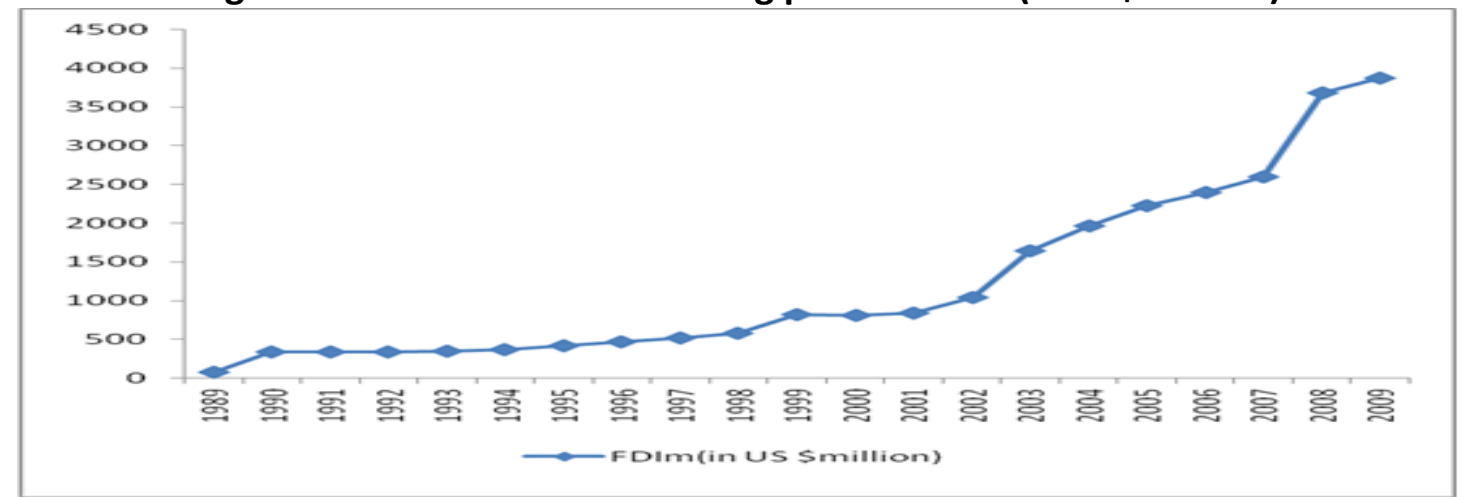

Source: Economic survey, 2009

\section{Literature Survey}

\section{Theoretical Perspective}

Theoretical linkage between export and FDI are well documented in literature where by export theory is culmination of a study by Adam Smith (1776), who investigated the nature and cause of wealth of countries. The underlying argument of the export theory is that "Countries need to export goods and services in order to generate revenue to finance imports which cannot be produced indigenously (McCombie and Thirlwall, 1992). Many studies on this area that have analyzed whether International trade influences GDP assume that as exports increase (ceteris paribus), the GDP of a country increases and spur economic growth. The study by Martin, 1992, point out that export theory can be interpreted in a way that the performance of exports has a stimulating effect on a country economy especially in a form of technical spillovers. 
From the theoretically perspective the relationship between export and FDI are complementary rather than substitutes if trade between two economies is based on their comparative advantages. However, if trade between the two countries is based on their absolute advantages, there may be substitution between trade and investment, as businesses decide to supply products and services through exports or FDI. The degree of complementarily between trade and investment therefore remains an empirical question. Culem (1988); Ozawa (1992); Ruggiero (1996); Ethier and Horn (1990); Wei, et al (1999) appears to predict that international trade and investment are complements, as firms take advantage of factor price differences through cross-border vertical production integration.

FDI and international trade are not only increasingly complementary and mutually supportive, but also increasingly inseparable as two sides of the process of economic globalization (Ruggiero, 1996). Furthermore, inward FDI may stimulate exports from domestic sectors through mining linkage or spill-over effects, especially through backward linkages, buying local-made intermediate inputs to produce exports (Haddad \& Harrison, 1993). This effect creates a strong demand stimulus for domestic enterprises and promotes exports. FDI is expected to affect exports from the export supply side of the host country. FDI may enhance export-oriented productivity, which further improves export performance. Others may argue that export leads to an increase in productivity that further attracts foreign investors to increase FDIs. Consecutively, exports contribute to growth by facilitating labour mobilization and capital accumulation.

Related literature investigates the relation of trade and FDI in the context of development issues. Based on the conceptual framework developed by Porter (1990); Ozawa (1992) formulated a comprehensive theory describing linkages between economic development and competitiveness that create international trade and FDI. Ozawa (1992), argues that an increase in trade flows occurs as a result of improved comparative advantage which in turn, is influenced by FDI.

The Heckscher-Ohlin model suggests that trade and FDI are stimulated by cross-country differences in factor endowments (Suranovic, 2007). The model also assumes that the equalization of factor prices across countries can be brought about either through international trade or through international mobility of factors of production. Factor mobility may expand trade if capital flows into industries in which domestic firms are at a comparative disadvantage. Modern theories that assume imperfect competition has similar predictions. The key features of such theories arise from the interaction between economies of scale, differences in national factor endowments and firm-specific managerial and production expertise.

Most economic theories seem to suggest that FDI and trade are interlinked. In Tanzania, FDI inflows have been influenced by the existence of mineral resources, among other factors. Also, the flow of FDI has also been driven by the economic policies pursued by the country. For example, since Tanzania adopted an open policy towards trade and investment, both FDI and exports have increased. Therefore, it is possible that FDI and exports can have a positive relation in Tanzania. 


\section{Empirical Literature}

Balasubramanyam (1996) analyses the relation between trade strategy, FDI and growth in developing countries in the context of endogenous growth theory. For a sample of LDCs, they show that the effect of FDI, in terms of enhanced growth is stronger in those countries that pursue export promotion than in countries pursuing an inward oriented Import Substitution (IS) policy. They tested their hypothesis for a cross section of 46 LDCs using annual averages over 1970 to 1985. The findings of the study indicate that, the output elasticity of foreign capital in EP countries was highly significant while that of IS countries was insignificant.

This empirical evidence supported Baghwats hypothesis Export-oriented strategy and the effect of FDI on average growth rate for the period 1970-85 for the cross-section of 46 countries as well as the sub-sample of countries that are deemed to pursue export-oriented strategy was found to be positive (Balasubramanyam et.al., 1996) and significant but not insignificant and sometimes negative for a sub-set of countries pursuing inward-oriented strategy.

In a related study, Kwan and Singh (1996) examined the determinants of FDI in developing countries. They found that among other factors, exports in general and manufacturing exports in particular, are significant determinants for high investment in a recipient country. Using standard regressions analysis and Granger causality tests, they found that the direction of causation is predominantly from exports to FDI. They identify export orientation as the strongest explanatory variable for attracting FDI.

Graham and Wada (2001) used an econometric model to examine the effects of FDI on growth and export performance of China. The study found that, in general, FDI contributed positively to export growth. In particular, it was found that total factor productivity growth did accelerate in the coastal regional of China where the bulk of FDI were found to have taken place relative to other regions of China.

Aloysius (2003) examined the effect of FDI on Export growth in Cameroon. The hypothesis of the study indicated that, FDI had a positive impact on Cameroon export performance. He also found evidence that FDI inflows contributed to higher supply capacity and spillover effects in Cameroon, leading to higher export growth during the period of study.

Kweka (2004) investigated the impact of international trade agreements on Tanzania trade performance whereby the factors which contributed to low performance have been highlighted. Many factors are at play that have engendered this poor performance, but domestic supply constraints have remained to be the main cause of low production and export performance. However, the literature shows that Tanzania is participating in many regional trade arrangements and negotiations such as with the EAC and SADC but still their contribution to the export performance is insignificant. (Paul and Hopper 2006)

In a related study, Johnson and Vuksic (2006); Lee et al (2007); Xuan and Xing (2008), found that, a significant positive econometric relationship between inward FDI and the host country's exports, or a one-way causality from inward FDI to exports ("FDI causes exports"), both implying that inward FDI promotes exports. In the study by Ekanayake, Vogel and Veeramacheneni (2003); Baliamoune-Lutz (2004); Pacheco-Lopez (2005), they found a two- 
way causality between inward FDI and exports ("FDI causes exports" as well as "exports cause FDI").

llomo (2007), in his study indicates that mineral resources are positively related to economic performance in United Arabs Emirates. The relationship is negatively related to economic growth for cross country analysis and Tanzania. The negative relationship in Tanzania may be explained by inappropriate policies and poor strategies to develop the mining sector. It is difficult to explicitly provide the reasons for the negative relationship in cross country analysis; practically, each country has specific factors that explain the nature of the relationship between mineral resources and, social and economic performance.

Temba (2008), investigated the impact of FDI on export performance on manufacturing sector in Tanzania, in his model he analyses the following variables which are exchange rate, domestic fixed asset investment, world demand, national GDP, and FDI, using Ordinary least square methods, he found that main determinants of Tanzania export performance in manufacturing sector include FDI, exchange rate, and world demand, Co- integration analysis indicate there is long run relationship between variables used i.e. export performance and foreign direct investment, it's assumed that the same effect also affect agricultural sector.

MITM (2008) report highlighted the factors which contribute to the overall poor export performance. The major factors are Technical Barriers to Trade (TBT) and Sanitary Phytosanitary Measures (SPS). Despite all those impediments, the report recommends diversification of export products and dissemination of market and product information to both Tanzania exporters and importers. The request further recommends local manufacturers and exporters to team up and form associations in order to achieve economies of scale.

On the other hand study by Jeon (1992) on several cross-country studies found support for the hypothesis of a negative relationship between FDI and exports. However, Sharma (2000) does not see any statistically significant impact of FDI on Indian exports. In contrast, other studies indicated that FDI actually has a positive effect on export performance of host countries (Cabral, 1995; Blake and Pain, 1994).

The New Theory of Economic Growth concludes that FDI may affect not only the level of output per capita but also its rate of growth. This literature has developed various arguments that explain why FDI may potentially enhance the growth rate of per capita income in the host country. The identified channels to boost economic growth include increased capital accumulation in the recipient economy, improved efficiency of locally owned host country firms via contract and demonstration effects, and their exposure to fierce competition, technological change, and human capital growth and increased exports. However, the extent to which FDI contributes to growth depends on the prevailing economic and social conditions or in short, the quality of economic and social environment of the recipient country (Buckley et al., 2002).

\section{Summary of the Literature survey and Gaps from the Study}

In general, the reviewed studies both theoretical and empirical suggest that, FDI contributed positively to export growth especially for countries that are deemed to pursue export- 
oriented strategy (EP). On the other hand the studies show insignificant contribution to export growth for the countries pursuing Import Substitution (IS) policies. It is evident from these studies that in order to enhance export capacity, countries have to put in place appropriate policies and good strategies that will address the supply side constrains. However the researchers investigated the impact of FDI in general and have not particularly investigated the impact of FDI on the sector.

This study intended to investigate the relationship between FDIs in mining and the impact on the export performance for the period of 1989-2009. Most studies undertaken so far to establish the relation between FDI and economic performance apply cross country regression analysis methodology. Only few case studies have been done, which have applied descriptive analysis methodology.

Unfortunately, cross country studies in this context have heterogeneous results which lack generality. They fail to explain the reasons for a number of exceptional cases. These can be well explained using country specific studies because in this case features of each specific country can be correlated to the results of analysis or nature of economic performance in mineral rich countries. This study intends to close methodological gap evident in previous studies.

\section{Theoretical Model}

In achieving the basic objective of this paper, Njong (2008) model is adopted to analyze the relationship impact of FDIs on export performance. His model was used in investigating the effects of FDI on export growth in Cameroon. The model is used with modification to examine the role of FDI in generating export capacity of mining sector in Tanzania; this is a linear model which is relevant to data that is used in this study. Therefore the model is expressed as;

$X=\alpha_{0}+\alpha_{1} X_{1}+\alpha_{2} X_{2}+\alpha_{3} X_{3}+\alpha_{4} X_{4}+a_{5} X_{5}+\alpha_{n} X_{n}+\mu$

The underlying objective is to establish whether FDI has been a significant determinant of the country's export performance. Therefore a multiple regression model in the analysis is used, exports as the dependent variable and five independent variables (FDI, EXPM, GDP, IFL and EXCHR).

Assumption is that Export Performance is a function of the following variables:

$\operatorname{EXP}_{T}=f\left(F D I_{M}, \operatorname{EXP}_{M}, E X C H R, G D P, I N F L\right)$

Where; EXPT - total exports performance of Tanzania to the world market; FDl $\mathrm{M}_{\mathrm{M}}$ - Foreign Direct Investment in mining; EXPM - Export of Mining Sector; EXCHR -Exchange rate ; INFLinflation; GDP Gross Domestic Product.

Substituting the log to reduce the variation in variables in the above model, it generate the below multiple regression model to be used in this study

$\log E X P_{T}=a_{0}+a_{1} \log F D I_{M}+a_{2} \log E X P_{M}+a_{3} \log E X C H R+a_{4} \log G D P+a_{5} \log I N F L+\mu$

Where $\mu$ represents an error term 
In principle, it is important to test the order of integration of each variable in a model, to establish whether it isnon-stationary and how many times the variable needs to be differenced to derive stationary series (Johansein et al, 2010). There are several ways of testing for the presence of unit root. For the case of this study, emphasis is on the Augmented Dickey-Fuller (ADF). Philip and Perron (1988), propose a non-parametric method of controlling for higher order serial correlation in a series. Contrary to ADF, Philip-Perron test makes a correction to the t-statistic of the dependent variables in the autoregressive process to account for the serial correlation in random term. As with the ADF test, one has to specify whether to include a constant and linear trend, or neither in the test regression. For the PP test, the truncation lag $q$ for the Newey-West correction is specified which is the number of periods of serial correlation to include in the analysis (Johansein et al., 2010).

\section{Hypothesis}

This study will test the following hypothesis

(i) FDI in mining and Export performance have a positive relationship.

\section{Data Source and Empirical Results \\ Data Sources}

An econometric analysis (Ordinary Least Square (OLS) techniques for regression analysis) is carried out to analyze the effects of FDI in the Mining Sector to Tanzania's Export Capacity.Data is drawn from different documents of industries including National Bureau of Statistics, Tanzania Revenue Authority, Bank of Tanzania, e-books, Journals, reliable internet sources such as World Trade Organization (WTO), COMTRADE, United Nations Conference on Trade and Development (UNCTAD) and International Trade Centre (ITC).

Summary statistics of variables used for analysis is presented in Table 1, descriptive statistics for the data were undertaken for variables in levels with Jarque- Bera test statistics to test the distribution of data. The results revealed that values of mean and median are close to each other coupled with low value of JarqueBera (less than 5.99) which is the critical value for normal distribution, signifying that all variables are normally distributed. The descriptive statistics, nevertheless, do not fully indicate the strength of which model to employ as that necessitates their supplement by more incisive quantitative analysis such as correlation coefficient matrix, unit root tests and co-integration tests

\section{Empirical Results}

The second aspect of OLS analysis is to carry the integration order of each variable used in the empirical models. As a necessary but not sufficient condition for co- integration is that each of the variables must be integrated of the same order and the order of integration must be greater than zero (Johansein et al, 2010). To achieve this, Phillip Perron test which is the nonparameter test, based on Phillips (1987) Z-test, is used here instead of ADF test, because it is the best as it involves transforming the test statistic to eliminate any autocorrelation in the model. The ADF test tends to be more popular but it is parametric in nature. After carrying out the test at levels, all variables were non-stationary except FDIM and total exports. According to Churls (1987), if time series variables are found to be non-stationary at levels, then the next step is to differentiate them until they becomes stationary. Non-stationarity in the data was eliminated by differencing. This means that, the null hypothesis of the presence 
of unit root in the variables was rejected after taking the first difference and therefore the data were said to be integrated of order (1). Table 2 summarizes the PP results at first difference.

\section{Testing for Co-integration}

The main theoretical argument of co-integration analysis is that even if individual variable is non-stationary, the group of variables may drift together. This implies that a linear combination of two or more such variables (time series) can be stationary. As shown in Table 2 , since variables are integrated at the same order, there is the need to test for co-integration relationships. The co-integration test results in Table 3 indicate the presence of long run equilibrium among the time series data. The implications of these results are that, even if individual variables are non-stationary, their linear combination may be stationary. The results obtained reject the null hypothesis of no co-integration among the variables at 1 percent level of significance. This implies that log of total exports, log of exports from mining, Log of Exchange rate, log of FDI from mining, Log of GDP and log of inflation are co-integrated.

\section{Error Correction Model}

According to Johansein et al (2010) since there is co-integration among dependent variables and its fundamentals, an error correction model has to be estimated by incorporating the lagged error correction term in the set of regressors. The error correction term is the residual from the static long run regression and it joins the set of differenced non-stationary variables to be estimated to capture both short run and long run dynamics. Following the Engel and Granger theorem, the original model reparameterized into an error correction model. An error correction term (ECT_1) is introduced in the model and hence the final model ready for regression anlaysis becomes;

\section{$d \log \times p t=\beta_{0}+\beta_{1} d \log d i+\beta_{2} d \log \times \operatorname{pm}+\beta_{3} d \log x c h t r \beta_{4} d \log D P+\beta_{5} d \log n t$ $+\beta_{6} E C \underline{T} 1+\mu$}

This model is estimated using Ordinary Least Square (OLS) for time series data covering years from 1989 - 2009. Thus, an error correction term lagged once (ECT_1), which is the residual from the long run equation of non stationary variables, is included as one of the explanatory variables in the general overparameterized error correction model of determinants of export performance equation. This term captures the long run relationship by attempt to correct deviations from the long run equilibrium path. Its coefficient can be interpreted as the speed of adjustment from short run behavior to long run equilibrium. The empirical results of the preferred model including the lagged once error term (ECMt-1), are summarized in table 4.

\section{Economic Interpretation of the Variables}

The results of preferred model show that the goodness of fit is satisfactory as indicated by the R-squared of 68 percent which implies that the observed factors that affect Tanzania export performance for the period of analysis is explained by the independent variables by 68 percent and the remaining 32 percent is explained by other variables excluded by the analysis for example Technical Barriers to Trade and other supply side constraints. Similarly, the model specification is significant at 1 percent level since the probability of rejecting is zero given by Prob. (F-statistic) of 0.0000 . This implies that the model is significantly explained by 
the explanatory variable hence acceptable in overall terms. There is no indication of serious autocorrelation problem basing on the information given by the Durbin- Watson (D-W) statistic of 2.4 which is close to conventional mark of 1.5 to 2.5 .

The findings on total exports show that the total exports performance to the rest of the world is negative and insignificant, which implies that the contribution of FDI in mining have been weakly and exerting negative pressure on Tanzania's export performance over the period. This result is contrary to the prediction that an increase FDI in mining leads to increase exports in mining that will result to increase in total export performance, On the other hand the coefficient of the present FDI mining is positive but insignificant. This is consistent with previous theoretical expectation; and it implies that despite its big size relative to other economic sectors, the present mining FDI has weakly been exerting negative pressure on Tanzania's export performance over the period.

Likewise, the findings show that FDI has no impact to the total Tanzania export performance and its contribution is insignificant but it accept the hypothesis of this study that FDI and Export performance have a positive relationship. This result can be also supported by the following empirical analysis. Jeon (1992) on several cross-country studies found support for the hypothesis of insignificanct relationship between FDI and export. Moreover, Sharma (2000) does not see any statistically significant impact of FDI on Indian exports. This finding suggests that benefits deriving from mining transformation do not turn up within the period when the investments are made, but possibly it takes some time for this to record. But it contradict with empirical analysis from Almelia and Santos (2000) who found out that in developing countries, foreign direct investment has significantly impact on export volumes since it changes their structure. Furthermore, Aloysius (2008) in investigating the effects of FDI on export growth in Cameroon found that, FDI has significantly contribution to higher exports, through improvements in the supply capacity of the economy that is, raising potential output.

The last variable that was tested is mining export which was introduced in the model in order to test whether the mining sector is important in the variation of total exports of the country. Results indicate that mining exports significantly affect the performance of the total exports in the country. Table 4 shows that the mining export is significant at 1 percent level and positive as expected. This can further be interpreted as elasticity of mining export to the total exports. That is, the responsiveness of total exports due to change in the exports from mining sector in 0.28 percent means that mining export contributes significantly but very minimal to the total exports.

\section{Summary and Conclusion}

This study concentrated in examining the role FDI in the Mining Sector to Tanzania's Export Capacity during 1989-2009. The study uses Ordinary Least Squares (OLS) as analytical techniques for this purpose. The results from OLS show that the total exports performance to the rest of the world is negative and insignificant, which implies that the contribution of FDI in mining have been weakly and exerting negative pressure on Tanzania's export performance over the period. The result on the relationship between Tanzania export performance and FDI in mining shows to be statically insignificant however it confirms the hypothesis of the positive relationship among the variables, this kind of results can justify that the benefits 
deriving from mining transformation do not turn up within the period when the investments are made, but possibly it takes some time for this to record.

It is therefore, suggested that there is a need to sustain current inflows and attract new FDI, but we can adjust this by enhancing the domestic investments in mining sector; addressing the supply and demand side constrains; accelerating growth in the sector by the interventions in reviewing and implementation of Mining Policy by targeting at value addition and improve export performance; facilitate exports of final products made of minerals rather than focusing on exporting raw gold, Tanzanite, diamond and other minerals; Improve physical infrastructure in the transport and communication sectors; Think in terms of quality, not quantity, Provide a link between small scale producers and large scale mining companies to ensure that both parties are benefiting from the sector; facilitate research and development in the mining sector; Align mining policies and other local and environmental policies to ensure sustainable development in the sector; and Provide a transparent and appropriate incentive and regulatory framework

\section{References}

Agarwa J. P. (1989), "Determinants and Structure Development of FDI in Pacific -Rim Developing Countries", Institut fur Weltwirtschatan der Universitant Kiel, Working Papers, 382

Agosin, M. A. (2000), Foreign Investment in Developing Countries: Does it Crowd in Domestic Investment? UNCTAD Press

Asseri, A. (2009), Unpublished Master thesis on spillover effects of foreign direct investments in the tanzanian manufacturing sector

Ahmad, M. H. A. S. (2003), Foreign Direct Investment, Exports and Domestic Output in Pakistan, The Pakistan Development Review, University press

Alinlo, A. E. (2004), "Foreign Direct Investment and Growth in Nigeria: An Empirical Investigation", Journal of Policy modeling, Volume 26.No.21

Balasubramanya, V. S. (1996), "Foreign direct investment and Growth in EP and IS countries", The Economic Journal, Volume 106, No 1

Changqi, W., \& Cheng, L. (1999), The Determinants of export Performance of China's Township-village Enterprises, China, Normal University Press.

Domician, T. C. (2007), Impact of FDI in Export Performance Lessons from Tanzania, Unpublished MIT Dissertation UDSM

Fosu, Y. K. (1992), The Real Exchange Rate and Ghana's Agricultural Exports Research, University of Nairobi Press

Fugazza, M. (2004), Export Performance and its Determinants: Supply and Demand Constraints.Geneva. UNCTAD Press

Johansein Rutaihwa and WumiOlayiwola. (2010), "Trade reform and employment performance of textile industry in Tanzania" Covenant Journal of Business and Social Sciences 3 (1\&2), 2010

Jones, R. (1956), "Factors Proportions and the Heckscher-Ohlin Theorem", Journal of Reviewing Economic Studies, Volume 24, No11

Kweka, J. (2005), Trade Performance Review 2005, Tanzania

Kumar, N. (1998), Multinational Enterprises, India, London Press 
Musinguzi \& Obwona. (2000), Determinant of foreign direct investments and their impact on economic growth, Uganda, Volume 13, No.4

Ngano, A. (1990), Comparative analysis of economic reform and structural adjustment programme in eastern Africa with emphasis on trade policies, Kenya, University of Nairobi Press, Technical Paper, No. 19\&20

Mcintyre, A. (1990), Determinants of Caribbean Export Performance, Caribbean, Greenwood Press

United Republic of Tanzania. (2009), Tanzania National Export Strategy

United Republic of Tanzania. (2009), Economic Survey, Dar es Salaam, Tanzania

United Republic of Tanzania. (2008), Economic Survey, Dar es Salaam, Tanzania

United Republic of Tanzania. (2003), National Trade Policy, Dar esSalaam,Tanzania.

UNCTAD. (2009), World Investment Report, Transnational Corporations, Agricultural Production and Development

UNCTAD. (2009), "Economic Development in Africa Report: Strengthening Regional Economic for Africa's Development" United Nations, Geneva and Washington.

UNCTAD. (2009), Enhancing the role of domestic financial resources in Africa's Development, A policy handbook

UNCTAD. (2002), Determinants of Export Performance

WumiOlayiwola \& Rutaihwa, J. (2010), "Trade Liberalization and Employment Performance of Textile and Clothing Industry in Tanzania" Journal of International Business Review Vol 3.No.3. 
INTERNATIONAL JOURNAL OF ACADEMIC RESEARCH IN PROGRESSIVE EDUCATION AND DEVELOPMENT

Vol. 1, No. 4, 2012, E-ISSN: 2226-6348 @ 2012 HRMARS

\section{Appendix}

Table 1: Summary of Descriptive Statistics Results

\begin{tabular}{|l|l|l|l|l|l|l|}
\hline & LGEXPM & LGEXPT & LGEXR & LGFDIM & LGGDP & LGINFL \\
\hline Mean & 5.023370 & 6.751134 & 6.459242 & 6.681173 & 1.651423 & 2.504763 \\
\hline Median & 4.294561 & 6.623534 & 6.613116 & 6.702206 & 1.740466 & 2.493205 \\
\hline Maximum & 7.043422 & 8.019613 & 7.185614 & 8.261139 & 2.054124 & 3.577948 \\
\hline Minimum & 3.273364 & 5.802118 & 4.965498 & 4.351000 & 1.064711 & 1.547563 \\
\hline Std. Dev. & 1.393798 & 0.697248 & 0.657945 & 0.994440 & 0.319817 & 0.736393 \\
\hline Skewness & 0.233512 & 0.415033 & -0.894190 & -0.173163 & -0.369009 & 0.090268 \\
\hline Kurtosis & 1.351995 & 2.043964 & 2.737194 & 2.650445 & 1.672291 & 1.433766 \\
\hline $\begin{array}{l}\text { Jarque- } \\
\text { Bera }\end{array}$ & 2.567277 & 1.402638 & 2.858949 & 0.211864 & 2.019046 & 2.174971 \\
\hline Probability & 0.277028 & 0.495931 & 0.239435 & 0.899486 & 0.364393 & 0.337063 \\
\hline $\begin{array}{l}\text { Observatio } \\
\text { ns }\end{array}$ & 21 & 21 & 21 & 21 & 21 & 21 \\
\hline
\end{tabular}

Source: Own Computation

Table 2: Unit Root Test Results: At first Difference

\begin{tabular}{|l|l|l|}
\hline Variable & PP Test Statistics & Order of Integration \\
\hline LOGEXPOT & -3.291866 & $\mathrm{I}(0)$ \\
\hline LOGEXPM & -4.437904 & $\mathrm{I}(0)$ \\
\hline LOGFDIM & -3.383846 & $\mathrm{I}(0)$ \\
\hline LOGGDP & -6.167725 & $\mathrm{I}(0)$ \\
\hline LOGEXCHR & -3.836537 & $\mathrm{I}(0)$ \\
\hline LOGINFL & -3.560625 & $\mathrm{I}(0)$ \\
\hline
\end{tabular}

Source: Own table, derived from data analysis

Note: (i) McKinnon (1980) critical values are used for rejection of the null of the Unit Root

(ii) I $(0)=$ the variable is stationary, I (1) = variable is integrated of order 1

(iii) Critical values for PP * 1 percent $=-3.8304$

$* * 5$ percent $=-3.0294$

$* * * 10$ percent $=-2.6552$

Table 3: Co -integration Test Results

\begin{tabular}{|l|l|l|}
\hline PP Test Statistic & Lagged Difference & Order of Integration \\
\hline-6.794305 & 1 & $1(0)$ \\
\hline
\end{tabular}

Source: Own table, derived from data analysis

Note:

$$
\begin{gathered}
* 1 \text { percent }=-3.8877 \\
* * 5 \text { percent }=-3.0521 \\
* * * 10 \text { percent }=-2.6672
\end{gathered}
$$


INTERNATIONAL JOURNAL OF ACADEMIC RESEARCH IN PROGRESSIVE EDUCATION AND DEVELOPMENT

Vol. 1, No. 4, 2012, E-ISSN: $2226-6348$ (C) 2012 HRMARS

Table 4: Estimated OLS Results of the Preferred Model

\begin{tabular}{|l|l|l|l|l|}
\hline & Coefficient & STD Error & t- Statistic & Prob. \\
\hline D.LOG EXPM & 0.280167 & 0.0744756 & 3.7619 & $0.00447^{*}$ \\
\hline D.LOGFDIM & 0.0391979 & 0.211863 & 0.1850 & 0.85782 \\
\hline D.LOGDP & 0.0860752 & 0.0354371 & 2.4290 & $0.04127^{* *}$ \\
\hline D.LOGINFL & -0.0136779 & 0.0179501 & -0.7620 & $0.046793^{* *}$ \\
\hline D.LOEXCHR & 0.485068 & 0.860182 & 0.5639 & $0.058827^{* * *}$ \\
\hline ECT_L1 & -0.0154914 & 0.00425131 & -3.6439 & $0.00655^{*}$ \\
\hline C & -0.00476078 & 0.0394273 & -0.1207 & 0.090687 \\
\hline R-squared & 0.68617 & & \\
\hline AdjustedR-square & 0.450797 & & \\
\hline Prob. (F- statistic) & 0.0000 & & \\
\hline Number of obs. & 21 & & \\
\hline Root MSE & 0.341 & & \\
\hline DW & 2.45317 & \\
\hline
\end{tabular}

Source: Own table, derived from data analysis

Note: ${ }^{*}=$ significance at 1 percent level

$* *=$ significance at 5 percent level

$* * *=$ significance at 10 percent level

$\mathrm{D}=$ differentiation

$\mathrm{LN}=$ natural logarithm 